\title{
Divine premotion
}

\author{
Article
}

Accepted Version

Oderberg, D. S. (2016) Divine premotion. International Journal for Philosophy of Religion, 794 (3). pp. 207-222. ISSN 15728684 doi: https://doi.org/10.1007/s11153-015-9536-z Available at https://centaur.reading.ac.uk/45787/

It is advisable to refer to the publisher's version if you intend to cite from the work. See Guidance on citing.

Published version at: http://link.springer.com/article/10.1007/s11153-015-9536-z

To link to this article DOI: http://dx.doi.org/10.1007/s11153-015-9536-z

Publisher: Springer

All outputs in CentAUR are protected by Intellectual Property Rights law, including copyright law. Copyright and IPR is retained by the creators or other copyright holders. Terms and conditions for use of this material are defined in the End User Agreement.

\section{www.reading.ac.uk/centaur}

\section{CentAUR}

Central Archive at the University of Reading

Reading's research outputs online 


\title{
Divine Premotion
}

\begin{abstract}
According to divine premotionism, God does not merely create and sustain the universe. He also moves all secondary causes to action as instruments without undermining their intrinsic causal efficacy. I explain and uphold the premotionist theory, which is the theory of St Thomas Aquinas and his most prominent exponents. I defend the premotionist interpretation of Aquinas in some textual detail, with particular reference to Suarez and to a recent paper by Louis Mancha. Critics, including Molinists and Suarezians, raise various objections to the view that premotion is compatible with genuine secondary causation. I rebut a number of these objections, in the course of which I $\mathbf{M} \mathrm{APN}$ challenge that premotionism destroys free will. I also offer a number of positive reasons for embracing the premotionist/4

\section{Introduction}

\section{ONLY!}

\section{NOT FOR CITATION}

Almost all participants in the medieval debate over divine providence profess agreement with, and to be faithful expositors of, the many Scriptural passages and doctrinal pronouncements affirming the pervasive role of God in the governance of worldly affairs. All agree that God is both creator and sustainer of all being.

Moreover, almost all agree that God as primary cause in some way 'concurs' with, or 'co-operates' with, the operations of secondary causes in nature. ${ }^{1}$

The sorts of passage to which all sides refer include: 'Lord, thou wilt give us peace: for thou hast wrought all our works for us'; 'Neither is he served with men' s hands, as though he needed any thing; seeing it is he who giveth to all life, and

\footnotetext{
${ }^{1}$ The famous exception being Durandus de Saint-Pourçain (c.1275-1332), whom Freddoso (1991: $555)$ calls 'the one and only well-known medieval proponent of mere conservationism'.

${ }^{2}$ Isaias 26:12. (All Scriptural citations use the Douay-Rheims translation.)
} 

CITATION. OFFICIAL VERSION IS PUBLISHED IN: INTERNATIONAL JOURNAL FOR PHILOSOPHY OF RELIGION, DOI 10.1007/s11153-015-9536-z

breath, and all things'; 'For in him we live, and move, and are';' and many others.

Again, the Fathers of the Church regarded it as both a natural and revealed truth, with St Augustine condemning Manicheans, Pelagians and others 'who reckon that it was only the world itself that was made by God, while everything else is now being made by this very world, as He arranged and commanded, but that God Himself does nothing; against whom we offer this statement of the Lord: "My Father is working until now." ${ }^{5}$ St Jerome, in his Dialogue against the Pelagians, ${ }^{6}$ takes up the orthodox position of Atticus, who asserts the Mrfosing anything without the

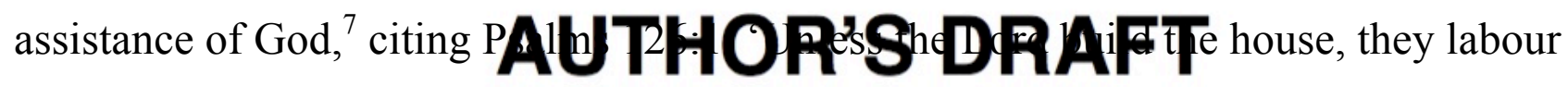
in vain that build it. Unless the Lord keed folty, watcheth in vain that keepeth

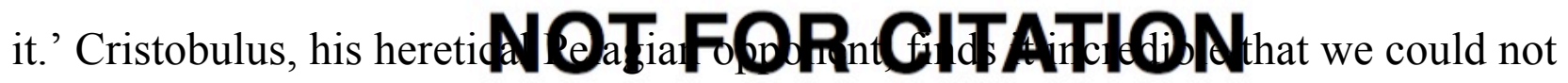
even make a pen or mend it, be silent or speak, sit or stand, or do anything unless God helped us.

This strong view of the role of God in the continuing operations of nature is echoed by the overall consensus of theologians, historically speaking, with the Roman Catechism giving an apt summary of the received position:

Not only does God protect and govern all things by His Providence, but He also, by an internal power impels to motion and action whatever

\footnotetext{
3 Acts 17:25.

4 Acts 17:28.

${ }^{5}$ St Augustine, On the Literal Meaning of Genesis 5.20, in Rotelle (2002): 296. (I have slightly amended the translation.) Note that in the cited passage from John 5:17, Christ adds '...and I work.' ${ }^{6}$ Book I, chs.2-3, Jerome (c.415).

${ }^{7}$ Dei utendum...Deus juverit...
} 
moves and acts, and this in such a manner that, although He excludes not, He yet precedes the agency of secondary causes. For His invisible influence extends to all things, and, as the Wise Man says, reaches from end to end mightily, and ordereth all things sweetly. ${ }^{8}$

Opinions famously diverge, however, when it comes to the interpretation of God's pervasive causal influence in the natural order. The most well-known difference is between Aquinas and the Thomists on one hand, who take an instrumental view of divine concurr Molinists on the other, whoAf directly into the debate, with all its nuaneAdeyetical difficulties, is in my view

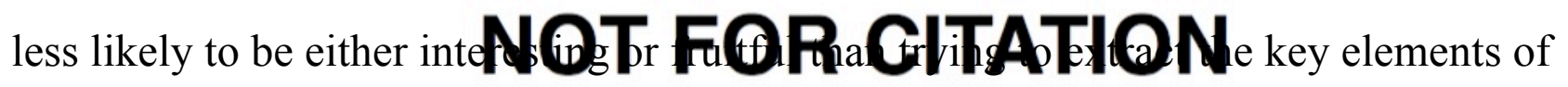
one view, explaining what they do and do not amount to, and defending their plausibility. The more plausible the view defended, the less plausible the alternatives are likely to be. I will directly address Molinism in some limited respects, contrasting it with the Thomistic view of divine concurrence. There will, however, be less about other competing views, save for occasional comments in passing and by way of contrast with the position I will defend. A final caveat is that much of the historic debate is at its most vigorous, and apparently significant, when the question of free human action is at issue. Although my focus will be on non-free secondary causes, I

\footnotetext{
${ }^{8}$ McHugh and Callan (1982): 30. The Scriptural quotation is from Wisdom 8:1. See also Wilhelm and Scannell (1909): 365-8 for an excellent summary of the received position, echoed by Ott (1974): 88-9 where the theological note 'sententia communis' is given to the proposition: 'God cooperates immediately in every act of His creatures'.
} 
WARNING - AUTHOR COPY ONLY. NOT OFFICIAL PUBLICATION. NOT FOR CITATION. OFFICIAL VERSION IS PUBLISHED IN: INTERNATIONAL JOURNAL FOR PHILOSOPHY OF RELIGION, DOI 10.1007/s11153-015-9536-z

will say something about how the premotionism dispute bears upon human freedom.

That said, the position I wish to defend is the Thomistic one taken at its strongest physical premotionism.

\section{What is premotionism?}

Premotionism takes as its starting point the idea of the total dependency of creatures on God: the universality explicit or implicit in the Scriptural passages above suggests that nothing whatsoever escapes the hands of Providence. Moreover, the use of verbs such as 'build', 'work', 'wrought indicates quite clearly that the hand is not AUTHOR'S DRAFT

a mere creating or conserving one. God is active in the works of nature, taking what OLI! might be called a poietic role in sublunary affairs.

What are the essential elements of divine premotion? The principal ones are as follows. ${ }^{10}$ (1) It is a motion received into the creature, applying it to act, and hence distinct both from the uncreated divine action constituted by the eternal decree that the creature shall act, and from the creaturely action causally resultant from the premotion. (2) It is a physical premotion - not in the sense that it is empirically measurable or subject to the laws of physics, but in contradistinction to merely moral or attractive premotion, whereby God inclines a secondary cause to move by virtue of proposing some end or object to be grasped by the patient as desirable. (3) Premotion is prior not in time but in terms of its place in the causal hierarchy. To use

\footnotetext{
9 'build' = 'yivneh', Ps. 126:1; 'work' = 'ergazetai', John 5:17; 'wrought' = 'pa'alta', Is. 26:12.

${ }^{10}$ For an excellent overview, see Garrigou-Lagrange (1939): ch. IV and Phillips (1962): Part II, ch.IX and Part III, ch.VII, to both of which I am indebted throughout this paper.
} 
WARNING - AUTHOR COPY ONLY. NOT OFFICIAL PUBLICATION. NOT FOR CITATION. OFFICIAL VERSION IS PUBLISHED IN: INTERNATIONAL JOURNAL FOR PHILOSOPHY OF RELIGION, DOI 10.1007/s11153-015-9536-z

a suggestive but very rough analogy, divine premotion is the metaphysical blood of the secondary causal system, permeating and inseparable from the action of secondary causes, but not prior to them in time. (4) It is predetermining in the sense that the secondary cause infallibly does what God moves it to do, but its modal status qua secondary cause is not affected. In other words, if the secondary cause necessarily acts, premotion does not affect this. If an effect is contingent, that it is moved by God makes no difference to its contingency. If an action is both contingent

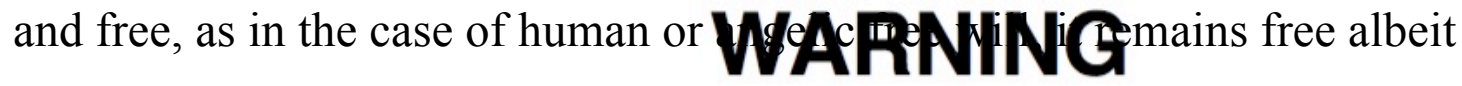
predetermined infallibly to Alattit/GR'S DRAFT

The most common and helpful way(Nder/ahding premotion is as a kind of

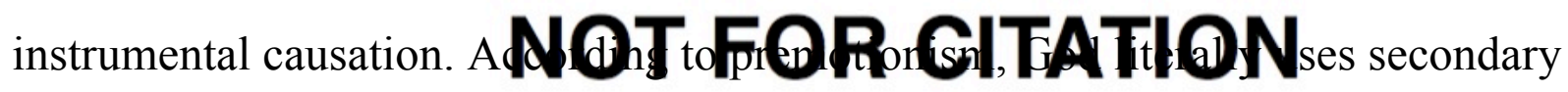
causes as instruments to the production of their effects. Instrumental causation requires: (i) the agent who uses the instrument; (ii) the instrument, which is passive inasmuch as it is in the hands of the agent; (iii) the application of the instrument to some action - whereby, to this extent, the instrument is active; (iv) the action resulting from the application of the instrument. The instrument itself must be of a suitable nature for application to a given action. To use the familiar analogy, if I want to cut bread I had better use a knife.

Premotionism, then, is opposed to mere conservationism, famously associated with Durandus de Saint-Pourçain in the medieval period, and also to Deism - the idea that God created the world and conserves it in being but in no way concurs with, in the sense of co-operating in, worldly affairs. It is also to be contrasted with 
WARNING - AUTHOR COPY ONLY. NOT OFFICIAL PUBLICATION. NOT FOR CITATION. OFFICIAL VERSION IS PUBLISHED IN: INTERNATIONAL JOURNAL FOR PHILOSOPHY OF RELIGION, DOI 10.1007/s11153-015-9536-z

occasionalism, most famously associated with Nicolas Malebranche (1638-1715) and his followers: ${ }^{11}$ this is the view that secondary causes do not produce anything but that God alone produces those effects we attribute to them. ${ }^{12}$ Neither mere conservationism nor occasionalism are consistent with the theological tradition taken in toto, nor is either plausible in its own right despite their surface attractions. They have received detailed examination by other writers and I will not pursue them here. ${ }^{13}$

\section{Physical premotion: what did Aquinas think?}

To many critics, no doubt, the be part of Aquinas's instrundtaln evokes the image of the hand of God reach ntythe innards of created beings like a divine puppeteer, pushing

Textually, this resistance likely has its roots in a famous passage of Aquinas's that does no favour to premotionism by virtue of its own apparent obscurity. St Thomas asserts in De Potentia: 'that which God does in a natural thing by which it operates actually is like a mere intention, incomplete in being, in the same way as colours are in the air and the power of art is in the craftsman's instrument.' 14

\footnotetext{
${ }^{11}$ Molina (1588: Part II, Disp. 25, n.3) attributes it to Gabriel Biel (c.1425-1495), following Peter D'Ailly (c.1350-1420). It had been espoused even earlier by Arabic philosophers including alGhazali (c.1058-1111): see Fakhry (1958). For Malebranche, see his The Search after Truth and the Elucidations (Malebranche 1678/1997).

${ }^{12}$ Such is Molina's statement of the position, but it is more accurate to define it as the theory that there are no secondary causes at all, only the one divine cause of everything that is or comes to be. Even specifying what the effects are is difficult: what the occasionalist must say is that God alone causes those effects that we would rightly attribute to what we call secondary causes were those causes in fact operative.

${ }^{13}$ For an important contemporary critique of mere conservationism, see Freddoso (1991). For Aquinas's critique of occasionalism, see Aquinas (c.1268): q.3 a.7, resp.

${ }^{14}$ De Potentia q.3 a.7 ad 7, Aquinas (c.1268).
} 
WARNING - AUTHOR COPY ONLY. NOT OFFICIAL PUBLICATION. NOT FOR CITATION. OFFICIAL VERSION IS PUBLISHED IN: INTERNATIONAL JOURNAL FOR PHILOSOPHY OF RELIGION, DOI 10.1007/s11153-015-9536-z

Before saying more about this passage and premotionism generally, it should be noted that Suarez believes ${ }^{15} \mathrm{St}$ Thomas retracted the position espoused in the above passage when he wrote about secondary causes in the Summa Theologica ${ }^{16}$ and the Summa Contra Gentiles, ${ }^{17}$ since in neither does he mention anything similar to what he does in De Potentia. I find this a curious objection, since scholars judge Aquinas to have written the Summa Contra Gentiles between 1259 and 1264 or 1265, De Potentia between 1265 and 1266, and the Summa Theologica between 1265 or 1266 and $1273 .{ }^{18}$ It is frankly impossible 1 ther or not Aquinas

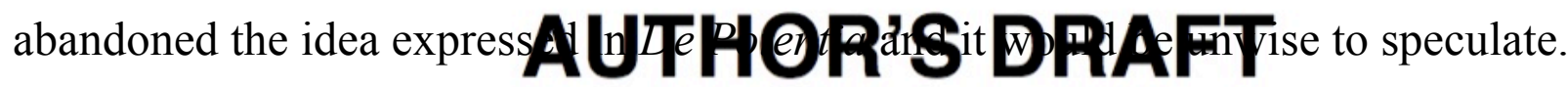
Rather, we should take it at face value that Nogsed an important view in an

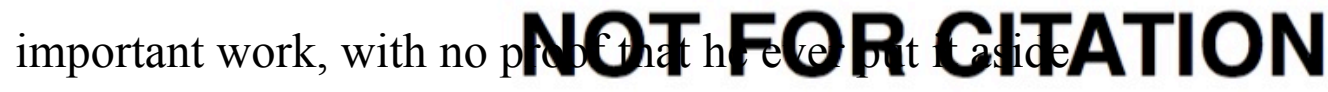

More important than the textual question, however, is whether, even if the idea expressed in De Potentia was Aquinas's settled view, it adds anything new to the premotionist theory. I submit that it does not. The full text in question is as follows:

Reply to the Seventh Objection. The natural powers implanted in natural things at their formation are in them by way of fixed and constant forms in nature. But that which God does in a natural thing by which it operates actually is like a mere intention, incomplete in being, in the same way as colours are in the air and the power of art is in the craftsman's instrument. Hence just as art can give the axe its sharpness as a permanent form, but not the power of the art as a permanent form, unless it were endowed with intelligence, so it is possible for a natural thing to be given its own proper power as a permanent form within it, but not the power to act so as to cause being as the instrument of the first cause, unless it were given to be the

\footnotetext{
${ }^{15}$ Disputates Metaphysicae (hereafter DM) 22.2.52, Suarez (1597/2002): 203.

${ }^{16}$ SummaTheologica (hereafter ST) I q.105 a.5, Aquinas (c.1273b/1922): 38-41.

${ }^{17}$ Summa Contra Gentiles (hereafter SCG) III.70, Aquinas (c.1264/1956): 235-7.

${ }^{18}$ Weisheipl (1983): 359-63 gives 1264 for the completion $S C G$ and 1266 for the commencement of $S T$; Davies (2012: 533) gives 1265 for $S C G$ and 1265 for $S T$.
} 


\section{WARNING - AUTHOR COPY ONLY. NOT OFFICIAL PUBLICATION. NOT FOR CITATION. OFFICIAL VERSION IS PUBLISHED IN: INTERNATIONAL JOURNAL FOR PHILOSOPHY OF RELIGION, DOI 10.1007/s11153-015-9536-z}

universal principle of being. Nor could it be given to a natural power to cause its own movement, or to preserve its own being. Consequently just as it clearly cannot be given to the craftsman's instrument to work unless it be moved by him, so neither can it be given to a natural thing to operate without the divine operation. ${ }^{19}$

It is easy to fixate (as does Suarez, and Louis Mancha following him on this point ${ }^{20}$ ) upon the 'mere intention...colours in the air' part of this passage but it is no more than a combination of metaphor on the one hand, which is of no special interest, and insight - where the insight is merely a way of putting what Aquinas says throughout the passage, and in copious other plap, abting which secondary causes work as instruments in relatAlth 'incompleteness in being' is but a contrast thyed and constant forms' that

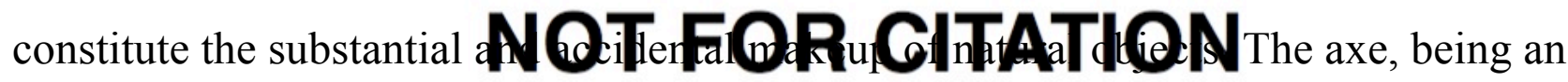
artefact, has both a substantial basis as a material object, and is combined with various accidents given to that lump of matter - shape, weight, hardness, sharpness to make it suitable for its purpose as a certain kind of cutting tool. The axe has the power to cut, to be sure - but only in the hands of the axeman. It is, as it were, ready to act, and so has the passive powers necessary for that readiness. But it is not

\footnotetext{
${ }^{19}$ Ad septimum dicendum, quod virtus naturalis quae est rebus naturalibus in sua institutione collata, inest eis ut quaedam forma habens esse ratum et firmum in natura. Sed id quod a Deo fit in re naturali, quo actualiter agat, est ut intentio sola, habens esse quoddam incompletum, per modum quo colores sunt in aere, et virtus artis in instrumento artificis. Sicut ergo securi per artem dari potuit acumen, ut esset forma in ea permanens, non autem dari ei potuit quod vis artis esset in ea quasi quaedam forma permanens, nisi haberet intellectum; ita rei naturali potuit conferri virtus propria, ut forma in ipsa permanens, non autem vis qua agit ad esse ut instrumentum primae causae; nisi daretur ei quod esset universale essendi principium: nec iterum virtuti naturali conferri potuit ut moveret se ipsam, nec ut conservaret se in esse: unde sicut patet quod instrumento artificis conferri non oportuit quod operaretur absque motu artis; ita rei naturali conferri non potuit quod operaretur absque operatione divina.

${ }^{20}$ Mancha (2012): 348ff.
} 

CITATION. OFFICIAL VERSION IS PUBLISHED IN: INTERNATIONAL JOURNAL FOR PHILOSOPHY OF RELIGION, DOI 10.1007/s11153-015-9536-z

capable of acting without being used; it has no active power that is not given to it by the axeman, and in this sense it lacks the 'power of the art' - something it could not have unless it had its own intelligence. Similarly, no creature without intelligence has the power to act unless it be used as an instrument of the primary cause.

Now, to appeal to a transient power - an active power that is passively received in the instrument so as to move it to $\mathrm{act}^{21}-$ is no more than to explain what has to happen in order for instrumental causation to take place. So when we consider what Aquinas says elsewhere about instrubstiste example that 'the artisan

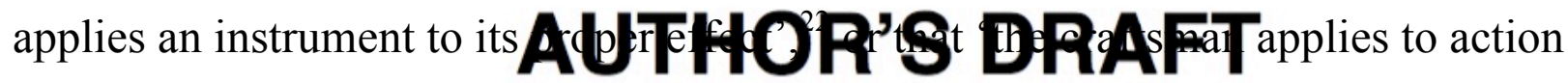
the axe, which cuts through its being shap 3 yould not think of the remarks in

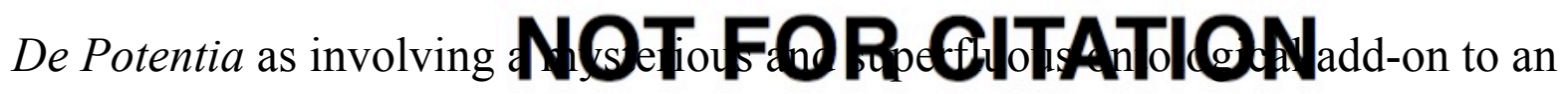
otherwise perfectly clear account of instrumental causation. Rather, we should see them as a clarification or elaboration of what that causation essentially involves. And here I ask the simple question: how could the axeman apply his axe to cut without giving it a transitory active power, one that is passively received by an object that can otherwise do nothing for itself? What does 'applying the instrument to its proper effect' involve if not that? This is what, when all is said and done, the physical premotionist insists upon.

\section{Physical premotion: replies to some objections}

\footnotetext{
${ }^{21}$ Garrigou-Lagrange (1939): 256.

${ }^{22}$ SCG III.70.5, Aquinas (c. 1264/1956): 236.

${ }^{23}$ ST I q.105 a.5, resp., Aquinas (c.1273b/1922): 40.
} 
Suarez is of the opinion that divine instrumental causation, as he understands $\mathrm{St}$

Thomas to have espoused it, is undermined rather than explained by the idea of physical premotion. One of his objections goes as follows, although the text is lacking in clarity. ${ }^{24}$ For the mere conservationist, the most God does is to produce and conserve the secondary cause, which is a 'per se principle of acting' ${ }^{25}$ the secondary cause, in other words, is essentially ordered towards certain kinds of effect. But that is the extent of God's concurrence: as far as the very effect of the secondary cause is concerned, He is only a 'remote and

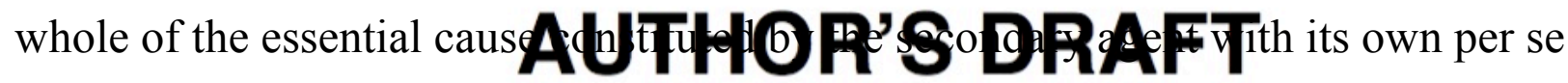
ordering to the effect. Now, the addition@ Nueçsary condition for acting, ${ }^{27}$ which

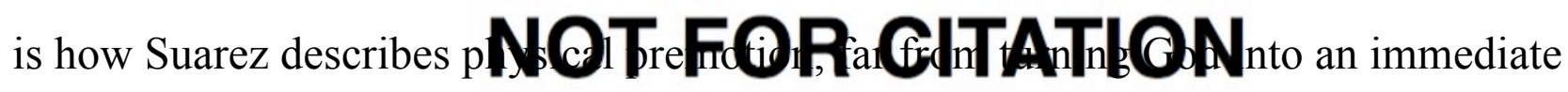
and per se rather than a remote, per accidens cause, does nothing of the kind. Rather, it adds just one more way of being a remote, per accidens cause, and so God 'will not concur per se in any way' with the effect. ${ }^{28}$

The objection is perplexing. Mancha thinks Suarez is saying that premotionism amounts to just another form of conservationism, ${ }^{29}$ but it is not clear he is arguing for quite this view; rather, he seems to be saying that premotionism is just as bad ${ }^{30}$ as mere conservationism in that it makes no room for an immediately concurring, per se

\footnotetext{
${ }^{24}$ DM 22.2.13, Suarez (1597/2002): 178.

25 'principium per se agendi'.

26 'solum remote et per accidens causat effectum'.

27 'conditionem requisitam ad agendum'.

28 'unde qui utrumque facit, duplici modo concurret per accidens, nullo tamen modo per se'.

${ }^{29}$ Mancha (2012): 352.

30 'no less false', 'non minus falsa'.
} 
WARNING - AUTHOR COPY ONLY. NOT OFFICIAL PUBLICATION. NOT FOR CITATION. OFFICIAL VERSION IS PUBLISHED IN: INTERNATIONAL JOURNAL FOR PHILOSOPHY OF RELIGION, DOI 10.1007/s11153-015-9536-z

divine cause. In any case, what is mystifying about the objection is why

premotionism should be characterised in either way. The 'necessary condition' for acting, as Suarez calls it, is in no way on an ontological par with the conditions furnished by creation and conservation. The extra condition is a motion - a physical, predetermining motion emanating from, but not identical with, the eternal and infallible divine decree. It is precisely the way in which God concurs immediately with creatures by moving them to act as His instruments. One might as well say that the carpenter is only a remote and pure hole in the wall because

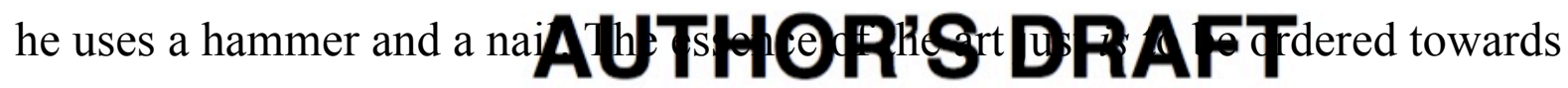
certain kinds of effect, so when the carp nes what carpenters do he acts as a per se cause, and immediately own action. And he can only do so by imparting to the tool a transient, instrumental motion - not something of the essence of the tool, but something the tool has the passive power to receive due to its essential features.

Another of Suarez's objections ${ }^{31}$ is, quite simply, the familiar one that premotionism is incompatible with free will. Details aside, Suarez's objection is that if the human agent, being a creature, needs a predetermining motion in order to act, then the will is not free either with respect to its exercise - being able to act or not to act - and its specification - being able to do A rather than the contrary. The reason is that the will, like any secondary instrument relative to the primary cause, must be in 

CITATION. OFFICIAL VERSION IS PUBLISHED IN: INTERNATIONAL JOURNAL FOR PHILOSOPHY OF RELIGION, DOI 10.1007/s11153-015-9536-z

passive potency with respect to receipt of the premotion. It has the passive power of receiving the premotion, but is no more free than any merely material object that is simply 'passively indifferent" ${ }^{, 32}$ with respect to the various forms it can take on under causal influence both secondary and primary. So it is 'not in the will's active and free power $^{, 33}$ to receive a determination to one act rather than another, or to action rather than inaction: it has to receive this from the outside, and cannot give it to itself.

Hence, 'since it is determined to only one act, it is able to effect that act and no other'. Again, "once the condition Nested in the will, it is impossible for the will Apt determination or its motion; therefore, a n w e $6 \mathrm{ds}$ the will have both the power to

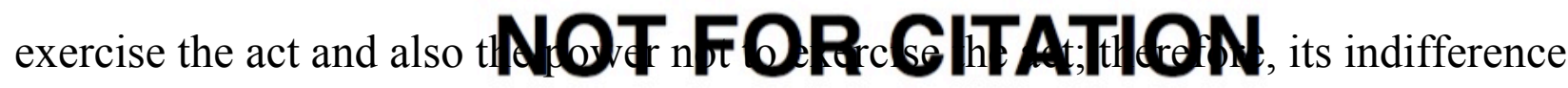
with respect to exercise, which consists in this power, is removed. ${ }^{35}$

There is much that can be and has been said about this well-known objection to premotionism. My reply will be relatively brief and suggestive, still less original, tying the issue to the more general considerations raised here. ${ }^{36}$ We should begin by disabusing ourselves of the notion that predetermining motion destroys the contingency of created being, any more than the determinism of secondary causation,

\footnotetext{
32 'passive indifferens'.

33 'Non est ergo in potestate activa et libera voluntatis ut hanc vel illam determinationem recipiat'.

34 'cum ergo ad unum tantum actum determinetur, illum potest efficere et non alium'.

35 'Rursus, posita in voluntate illa conditione. quae praedeterminatio dicitur, fieri non potest quin ipsa exerceat actum; nec potest resistere determinationi seu motioni eius; ergo nunquam habet potestatem exercendi et non exercendi actum; ergo tollitur indifferentia quoad exercitium, quae in hac potestate consistit.'

${ }^{36}$ See further Garrigou-Lagrange (1936); (1939), ch.VIII.
} 
WARNING - AUTHOR COPY ONLY. NOT OFFICIAL PUBLICATION. NOT FOR CITATION. OFFICIAL VERSION IS PUBLISHED IN: INTERNATIONAL JOURNAL FOR PHILOSOPHY OF RELIGION, DOI 10.1007/s11153-015-9536-z

if it obtains, destroys contingency. That B follows from A necessarily by some exceptionless law of nature does not entail that B itself is necessary. The same applies to the created human will. Even if - we should deny - secondary causal determinism were true of all created being, this would be compatible with the contingency of human acts. Divine physical premotionism - which we should accept - is also compatible with the contingency of human acts.

Needless to say, however, there is more to freedom than contingency. Freedom essentially involves the power to maN/ANAN rather than another.

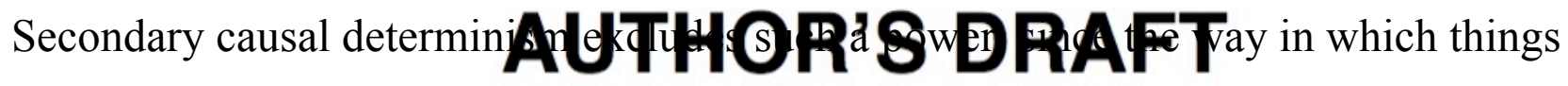
go is, ex hypothesi, causally necessitated (b) Whectant conditions. In the case of

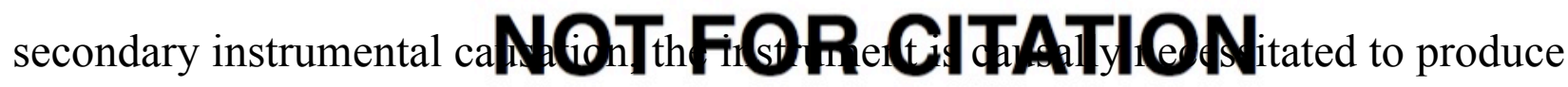
its effect by the craftsman's application. The instrument has no life of its own, qua instrument (even living things can be used as instruments), though it still contributes causally to the effect in virtue of its own proper powers. The question is whether divine instrumental causation must be regarded in the same way as secondary instrumental causation. Whereas we can accept that if freedom exists secondary determinism as a universal thesis must be false, we cannot, if we accept premotionism, accept that freedom excludes divine predetermination. Hence premotionism must be shown to be compatible with freedom, and so it must be shown to be a non-necessitating physical predetermination. That it is physical is not of itself a problem unless physical motion must be necessitating. That it is predetermining is not of itself a problem since this is no more than a characterisation 
WARNING - AUTHOR COPY ONLY. NOT OFFICIAL PUBLICATION. NOT FOR CITATION. OFFICIAL VERSION IS PUBLISHED IN: INTERNATIONAL JOURNAL FOR PHILOSOPHY OF RELIGION, DOI 10.1007/s11153-015-9536-z

of the infallible divine decree. Must an infallible divine decree accompanied by a transient physical motion be necessitating? I do not think so, and offer an example from secondary causation to suggest how this might be.

I am currently teaching my son how to write. When I do so, I sometimes hold his hand while it grips the pencil, guiding his formation of the letters. Sometimes I force his hand to move in a certain direction, to be sure, but most of the time I do not. So let us focus on the times I do not force his hand. My son has free will: he has the power within himself not to comply not, and his hand moves wiftly that transgression: if he wants to depart rofillance he can, since I am not

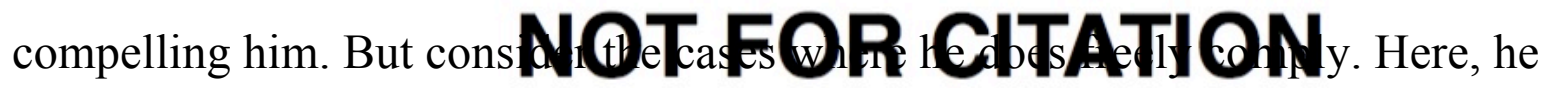
willingly submits to my physical guidance (not to mention my moral exhortation) and moves his hand in accordance with the motion of my own guiding hand. Although my son has the power to do otherwise, he does not exercise it. Why? Because he wants to comply, whether because he knows it is good for him, he wants to please me, is afraid of chastisement if he does not, or some combination thereof (which is most likely). He has not lost his freedom when I guide him; on the contrary, he exercises it. We can add more to the picture. Suppose I know that he will comply when he does comply; perhaps I know that he only fails to comply when he is in a bad mood, or tired, or some such. Again, his freedom is not lost. Now suppose that my will is sovereign in the matter of compliance, in this sense: when he complies, I will that he complies, and when he fails to comply I permit him to fail. What could it 
mean for me to will him to comply? It cannot mean that when I will him to write his name, for example, he simply does so; for I have no such power. I have to manifest my will in some way amenable to his nature: I can command him, of course; I can compel him physically; or I can guide him physically. Now, I can command him without his losing his freedom, but that is not the case under consideration. If I compel him he loses his freedom, but that is also not what we are envisaging. Rather, I guide him physically, without his losing his freedom, but this guidance is still a manifestation of my sovereign will WhANHW

What exactly does it nAdo that all it means is that my son is free no(T) but that he must accept the

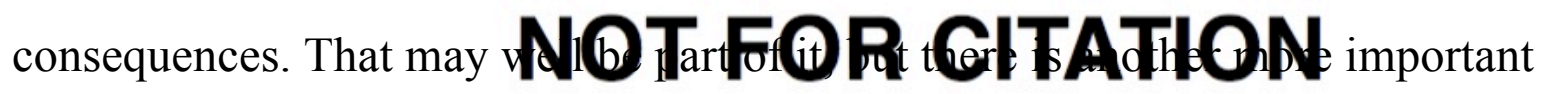
element: given my son's nature, inasmuch as he seeks to please me, to obey, thinks I have his best interests at heart, and so on, and given also my intimate knowledge of my son's nature, there is a non-accidental correlation between what I will and what he does. It is no coincidence that when I want him to make an effort to write neatly, he writes neatly, and the like. So my will can be sovereign over his without his losing any of his freedom.

There are, of course, major differences between the divine and the human case. For one thing, God can will a person to do $\mathrm{X}$ and they just do it; contrary to occasionalism, however, this is not the normal mode of divine operation. A direct movement from divine will to human act would be miraculous activity, not divine concurrence. Secondly, and related to the first point, the way in which God operates 

CITATION. OFFICIAL VERSION IS PUBLISHED IN: INTERNATIONAL JOURNAL FOR PHILOSOPHY OF RELIGION, DOI 10.1007/s11153-015-9536-z in respect of human freedom is through infallibly intimate knowledge of human nature. I do not know nearly everything about my son's innermost thoughts and inclinations, so I am unable infallibly to move him to act in the way I interiorly decree. By contrast, God possesses perfect knowledge and so is able infallibly to move the human will in accordance with His eternal, predetermining decree. Yet this perfection of knowledge does not destroy human freedom; at least, we need a good argument as to why it would. Thirdly, when my son transgresses in his writing activity by, say, making a scribble rotrath responsible for the transgre Aidn act of moving the pencil in a certain diret $\mathbf{N}$ By

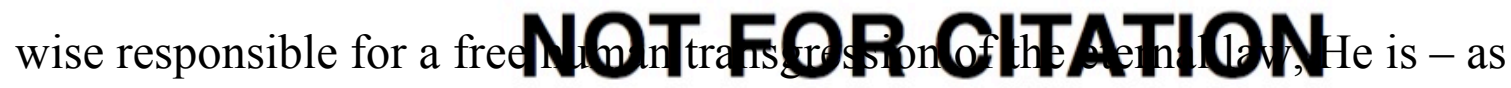
predetermining mover of the will - responsible for the underlying positive act on which the transgression supervenes. For it will be just another human action, and all positive being is wholly dependent upon God for its continuing activity as well as its creation and persistence. Yet how could this be, given that the positive act grounds a transgressive one? The answer is in the very human nature with which God concurs. All human acts aim at some good or other, real or apparent. Human nature is built to desire the good, yet no good compels its own pursuit apart from that universal, ultimate good which is final beatification. Short of that, humans have the power to 
the greater good. This wonderful passage from Aquinas sums up the position: ${ }^{37}$

Since the nature of the good is the nature of the appetible, ..., and since evil is opposed to good, it is impossible that any evil as such be desired by an appetite, either natural, or animal, or intellectual, which is the will. Nevertheless, some evil may be desired (appetitur) accidentally insofar as it is consequent upon some good, and this appears in each appetite. ... The evil, however, which is joined to some good is the privation of another good. Never, therefore, would evil be desired, not even accidentally, unless the good to which it is joined were more desired that the good which is taken away by the evil.

Given, then, that human nature is buWASTHPeg even when a human agent

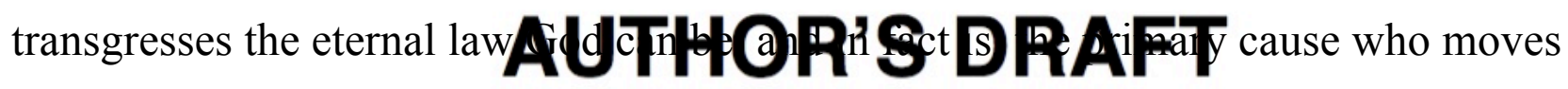
the agent's underlying positive act in acOAdeYith the latter's free nature. What

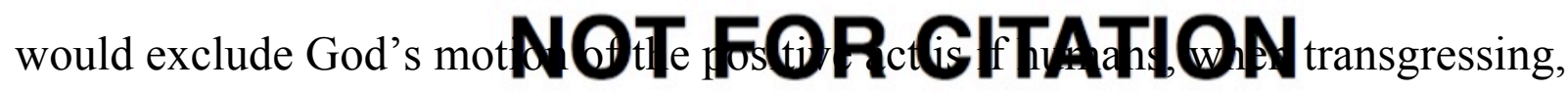
were capable of desiring the transgression qua transgression - evil qua evil rather than sub specie boni. In that case, God would have to concur per se with the evil act and hence be its primary agent, which is impossible. ${ }^{38}$

\section{Is the premotionist a compatibilist?}

This outline of how the premotionist maintains freedom of the will consistently with his position is likely to provoke the charge that it is tantamount to accepting a form of compatibilism - that between divine causation and human freedom. I reply that the premotionist must be a compatibilist of this kind; indeed, so should anyone

\footnotetext{
${ }^{37}$ ST I q.19 a.9, resp., Aquinas (c.1273a/1920): 279.

${ }^{38} \mathrm{I}$ am, of course, advocating the well-known Guise of the Good thesis. For a defence, see Oderberg (2015).
} 
WARNING - AUTHOR COPY ONLY. NOT OFFICIAL PUBLICATION. NOT FOR CITATION. OFFICIAL VERSION IS PUBLISHED IN: INTERNATIONAL JOURNAL FOR PHILOSOPHY OF RELIGION, DOI 10.1007/s11153-015-9536-z

who holds relatively orthodox views about divine providence and concurrence. Yet

for all that this looks like a concession to the view that theological determinism destroys 'libertarian' free will, as the metaphysically substantial kind of freedom is usually called, this is not the case. Freedom of the will should not - either for the theist or the atheist - ever have meant total independence of all causation whatsoever. If the 'libertarian' is searching for a justification of this supposed sort of freedom, he searches in vain. The free act of a finite agent essentially involves the actualisation of a potency; yet no potency can actua Wifer

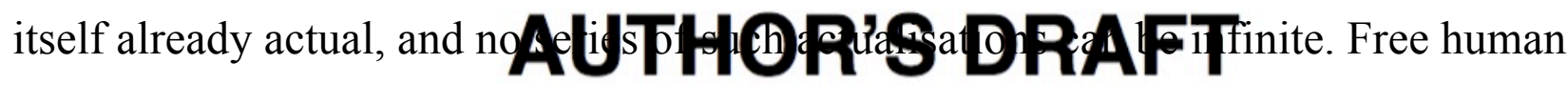

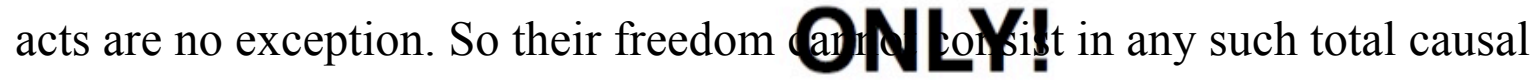

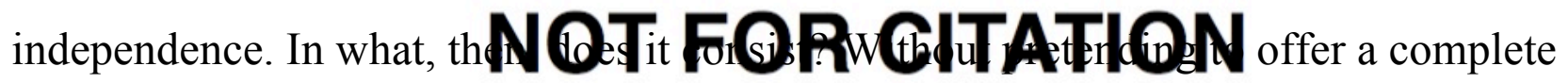
answer, I note that whatever freedom amounts to, it at least requires the nonnecessitation of the free act by secondary causes - and this is both compatible with, and preserved by, divine predetermining premotion. Such non-necessitation entails the power to do other than what the agent actually does (Frankfurt-style complications aside) given the secondary causes in actual operation. Does this 'leeway', as it is often called, extend further? For the premotionist it cannot extend beyond all the causes in actual operation, since this would entail the agent's independence of the divine sovereignty and its infallibly efficacious decrees.

Yet why, precisely, should this be a problem? Here, no doubt, the critic will invoke one of the various 'transfer' principles much discussed in the free will literature (on which, for an interesting recent contribution, see Pruss 2013). He might 
WARNING - AUTHOR COPY ONLY. NOT OFFICIAL PUBLICATION. NOT FOR CITATION. OFFICIAL VERSION IS PUBLISHED IN: INTERNATIONAL JOURNAL FOR PHILOSOPHY OF RELIGION, DOI 10.1007/s11153-015-9536-z

propose an operator such as ' $\mathrm{X}$ never has a choice about whether or not $\mathrm{P}$ ', or ' $\mathrm{X}$ has no power causally to falsify $\mathrm{P}^{\prime}$, for some agent $\mathrm{X}$ and proposition $\mathrm{P}$. He might then argue as follows. If God moves $\mathrm{S}$ to perform $\mathrm{A}$, for particular agent $\mathrm{S}$ and action $\mathrm{A}$, then S never has a choice about whether or not God so moves him. (Reason: God's total independence of all creatures.) If God moves $\mathrm{S}$ to perform $\mathrm{A}$, this logically entails that S performs A. (Reason: the infallible efficaciousness of the divine decree.) By transfer of necessity (the necessity of the operator just introduced), $S$ never has a choice about whether or WARAHNO it seems that divine predetermining premotion Acts insistence of Thomists that this is not th@NLY!

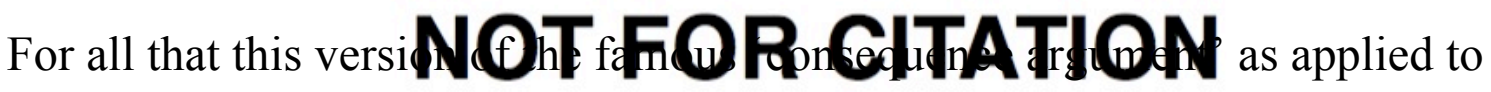
premotionism looks like a bulldozer to metaphysically substantial freedom, appearances are deceptive. It might not be possible here fully to define metaphysically substantial freedom, but let us suppose the following: (i) it involves leeway that is independent of secondary causes; (ii) it involves in addition some set of agential properties $\mathrm{F}_{1} \ldots \mathrm{F}_{\mathrm{n}}$ up to but not including independence of divine predetermining premotion. In other words, think of metaphysically substantial freedom as being as substantial as can be short of independence of the sovereign divine providence. The premotionist claims that God moves every free human act in the sense of 'freedom' just delineated. Given this sense, the appropriate transfer principle (framed in terms of a necessity operator such as those given above) will be invalid. For no agent will, ex hypothesi, have a choice about whether God moves him 
WARNING - AUTHOR COPY ONLY. NOT OFFICIAL PUBLICATION. NOT FOR CITATION. OFFICIAL VERSION IS PUBLISHED IN: INTERNATIONAL JOURNAL FOR PHILOSOPHY OF RELIGION, DOI 10.1007/s11153-015-9536-z

freely to perform act A. God's moving an agent so to act will entail his freely

performing A. But every agent will still have a choice about whether freely to

perform A. Indeed, given that he freely performs A, it will be a truism that he has a choice about it, if not a tautology!

The theological necessitarian will, no doubt, respond that the premotionist begs the question: for how can God infallibly move an agent freely to perform an act?

Surely something has to give? The premotionist response, apart from repeating the very considerations adduced earlier, if what could it mean for God/4 body to move in certain ways correspon (ii) WWattwe call action'? Does it mean

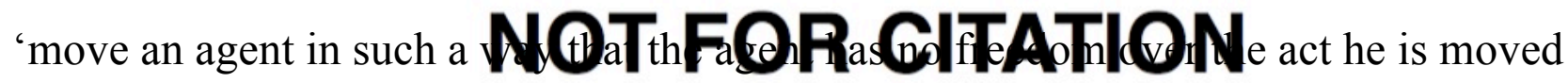
to perform'? The premotionist sees such construals of divine predetermination as either radically incomplete or else as amounting to a flat-out (and question-begging) denial of the premotionist theory. It is no surprise that if the opponent formulates the relevant transfer principle in a way that embodies such conceptions of action, the principle will turn out valid and the agent will lack metaphysically substantial freedom. But the premotionist refuses such formulations in the first place. Now, the opponent will make the same charge against the premotionist: if God is deemed to move the agent freely to act, then it is no surprise the transfer principle comes out as invalid. But where does this leave us? The short way of ending the dispute is to concede the point and conclude that transfer principles prove nothing one way or the other in this context; in other words, they are dialectically useless and the theological 

CITATION. OFFICIAL VERSION IS PUBLISHED IN: INTERNATIONAL JOURNAL FOR PHILOSOPHY OF RELIGION, DOI 10.1007/s11153-015-9536-z necessitarian cannot appeal to them. The dispute, then, has to be settled on other grounds. The more interesting response by the premotionist, however, is that his invalidation of transfer principles here is dialectically above board in a way that the necessitarian's is not. For the latter, by his very formulation of God's 'moving an agent to act', either assumes there is no room at all for metaphysically substantial freedom or appeals to a conception of 'moving an agent to act' that is radically incomplete to the point of vacuity or irrelevance (moving bodies or body parts in certain characteristic ways, and the with a precise conception oArtg with all the metaphysical freedom an ag (n) hald to but not including

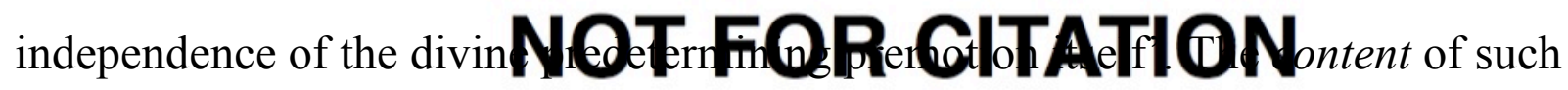
freedom may be a matter of debate, but its limits are not. The premotionist, then, can use this conception to invalidate the very transfer principles that the necessitarian cannot defend without a question-begging or else radically deficient conception of divine causation.

\section{Physical premotion: why we should believe it}

We should believe in physical premotion precisely for the reason already suggested: there is no sense to be made of divine instrumental causation without it, just as there is no sense to be made of any lower instrumental causation. Some transient power must be passively received by the instrument if it is to be applied as an instrument, moving it to act. Premotionism is not merely the view that there is 
WARNING - AUTHOR COPY ONLY. NOT OFFICIAL PUBLICATION. NOT FOR CITATION. OFFICIAL VERSION IS PUBLISHED IN: INTERNATIONAL JOURNAL FOR PHILOSOPHY OF RELIGION, DOI 10.1007/s11153-015-9536-z

such a power: that there is such a power is how premotionism explains the way in which God moves all of creation, and it is the view that God does move all of creation that constitutes premotionism proper, setting believers in exceptionless divine instrumental causation apart from occcasionalists, mere conservationists, and Molinists.

Far more of a positive nature can be said in favour of premotionism. ${ }^{39}$ First, to elaborate on the point just made, if instrumental causation is the correct model of divine concurrence, then physical prybes instrumental operation has A d the power to produce the instrumental e fselfouse then the instrument would not be an instrument after Av, bethe for wood but it cannot of itself chop wood purely and simply. Hence it must receive an additional power to produce the effect, and this it can only receive from the principal cause. Even if, then (a matter of some debate, to be sure), St Thomas explicitly mentions physical premotion only once, it is evident that the following statement from De Veritate, indeed the entire passage from which it is taken, amounts to the closest thing to an explicit statement of premotionism that one can expect, given Aquinas's commitment to the instrumental model: ${ }^{40}$

It is the nature of an instrument as instrument to move something else when moved itself. ... Thus an instrument has two operations, one which belongs

\footnotetext{
${ }^{39}$ Here I am indebted to Phillips (1962).

${ }^{40}$ De Veritatae q.27 a.4, resp., Aquinas (c.1259): Haec enim est ratio instrumenti, in quantum est instrumentum, ut moveat motum...Et sic instrumentum habet duas operationes: unam quae competit ei secundum formam propriam; aliam quae competit ei secundum quod est motum a per se agente, quae transcendit virtutem propriae formae.
} 
to it according to its own form, and another which belongs to it in so far as it is moved by the principal agent and which rises above the ability of its own form.

Secondly, could the instrumental power be, as Suarez thought ${ }^{41}$, an 'active obediential potency proper to the instrument whether in use or not? No, because then we would have to say that the axe was after all capable, of itself, of chopping wood even when not under the influence of the principal cause. Contrast this with, say, the magnetisation of a screwdriver by contact with a magnet: once the tool is magnetised, then the principal cause of magnetis retain the active power of a Adth screwdriver will lose its magnetism afte a Wile: Yd point is that the change effected in it is not transitory in the $\mathrm{Nes}$ seis does not require the continued influence of the principal cause.

Thirdly, in further defence of the first point, if the secondary cause is a true instrument then the assistance it receives in producing its effect cannot be merely extrinsic, that is to say a help that it receives without internally affecting the instrument in some way. The secondary cause produces an effect it cannot even partially produce under its own power. If the help it receives is merely extrinsic, not affecting the very nature of the secondary cause, then in what way can the effect be attributed to it at all? Shouldn't we say, rather, that the whole of the effect is due to the principal cause? The secondary cause's powers will not have been altered in any

\footnotetext{
${ }^{41}$ DM 17.2., Suarez (1597/2002): 30-1. Suarez does not use the term 'active obediential potency' here but he accepts that the instrumental power might be permanent and endure after cessation of the instrumental action; which looks like acceptance of active obediential potency in some cases.
} 
WARNING - AUTHOR COPY ONLY. NOT OFFICIAL PUBLICATION. NOT FOR CITATION. OFFICIAL VERSION IS PUBLISHED IN: INTERNATIONAL JOURNAL FOR PHILOSOPHY OF RELIGION, DOI 10.1007/s11153-015-9536-z

way, and so its contribution to the effect will be the same as if it had not been used at all. Not only does it make no sense on this interpretation to call the secondary cause an instrument, but the door is once again wide open to occasionalism.

We must affirm, therefore, that the assistance received by the secondary cause is intrinsic - an assistance that confers a transient power affecting the instrument in its nature, making it capable of doing something it could not do unaided. In this way, the secondary cause becomes a true instrument and a true cause, rather than a mere 'medium for the passage of the pow $N$ the

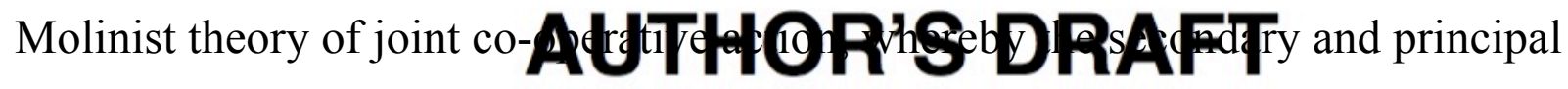

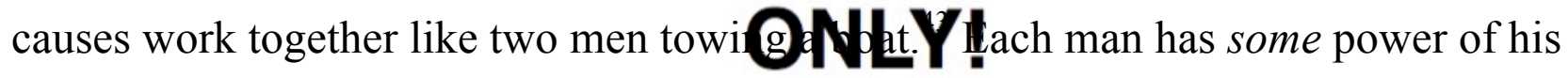

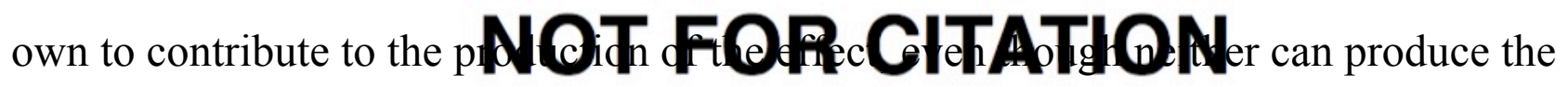
effect on his own. The assistance each gives the other is purely extrinsic, adding to what the other is able to contribute by himself. We cannot call this a case of instrumental causation, since neither man depends instrumentally on the other even though they do depend on each other for the production of the effect. Not only is there no instrumental dependence because each is able to contribute something unaided to the production of the effect, but the dependence that does exist is symmetrical: each depends on the other even if one man happens to be stronger than the other and so contributes more to the production of the effect. With instrumental causation, the instrument depends wholly on the principal agent but not vice versa.

\footnotetext{
42 Phillips (1962): 244.

${ }^{43}$ Molina (1588): Part II, Disp. 25, n.12, Disp. 26, n.15.
} 
WARNING - AUTHOR COPY ONLY. NOT OFFICIAL PUBLICATION. NOT FOR CITATION. OFFICIAL VERSION IS PUBLISHED IN: INTERNATIONAL JOURNAL FOR PHILOSOPHY OF RELIGION, DOI 10.1007/s11153-015-9536-z

But we must be precise: the carpenter needs the saw to be able to cut the wood, and he needs the saw to have the properties that make is suitable for so doing. So in one sense he can be said to depend on the saw. But this is not a causal dependence: causally, the action flows from principal to instrument, not the other way around. On the Molinist model, there is no causal dependence in either direction, but there is symmetrical non-causal dependence, inasmuch as each man needs the extrinsic assistance of the other to tow the boat. So on the instrumental model we have asymmetrical causal dependence, wNATHNDist model we have symmetrical non-causal deAdUTFHOR'S DRAFT

Whatever the Molinist model has ir(1) Nov ihsofar as the free will question is

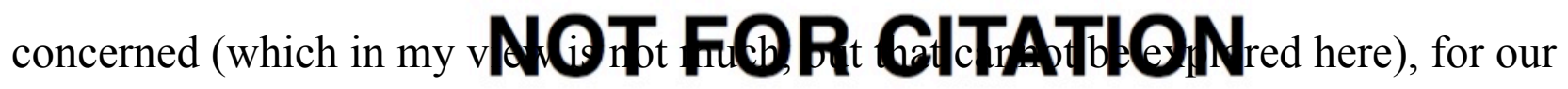
purposes it leaves Molinism wide open to the objection that secondary causes are no longer able to be considered whole causes of their effects: as joint co-operative causes with the principal cause, they only ever contribute partially to their natural effects, and in doing so they contribute independently of God. It is difficult to know exactly what God contributes and what the secondary cause contributes, contrary to the instrumental model; it is hard to see how the Molinist model is any serious improvement on occasionalism; and there is no easy reconciliation of Molinism with the complete dependence of all things on God "who worketh all things according to the counsel of His will. ${ }^{, 4}$

${ }^{44}$ Ephesians 1:11. 
It would be foolish to pretend that we can speedily resolve a debate about secondary causation that is centuries in duration. Further, it is unfortunate that positions on the matter have hardened over time, putting the competing schools of thought at odds to an extent that seems unbreachable. All I have attempted here is to remove some of the many confusions surrounding premotionism, which seems to be greatly out of favour in contemporary philosophy. When understood correctly, premotionism provides a plausible -W/APR

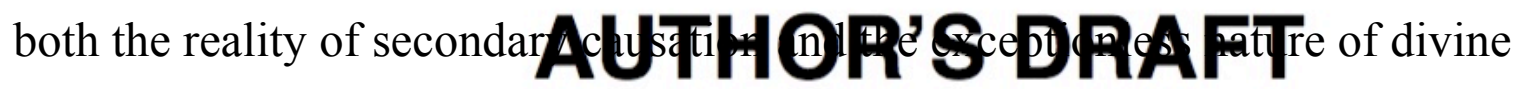
concurrence. At the very least it deserve (1) N/r. $/$ stussion. ${ }^{45}$

\section{NOT FOR CITATION}

\section{Bibliography}

Aquinas, St T. (c.1273a/1920) The 'Summa Theologica' of St Thomas Aquinas,

Literally Translated by Fathers of the English Dominican Province, vol. 1

(London: Burns Oates \& Washbourne Ltd).

Aquinas, St T. (c.1273b/1922) The 'Summa Theologica' of St Thomas Aquinas,

Literally Translated by Fathers of the English Dominican Province, vol. 5

(London: Burns Oates \& Washbourne Ltd).

\footnotetext{
${ }^{45}$ An earlier version of this paper was given at the Workshop on Continuous Creation organized by Paul Clavier and held at the Ecole Normale Supérieure, Paris, in December 2014. I am grateful to the participants for their comments, especially Alexander Pruss and Cyrille Michon. I also thank Prof. Michon for extensive correspondence afterwards.
} 
WARNING - AUTHOR COPY ONLY. NOT OFFICIAL PUBLICATION. NOT FOR CITATION. OFFICIAL VERSION IS PUBLISHED IN: INTERNATIONAL JOURNAL FOR PHILOSOPHY OF RELIGION, DOI 10.1007/s11153-015-9536-z

Aquinas, St T. (c.1268) Quaestiones Disputatae de Potentia Dei, at

http://dhspriory.org/thomas/QDdePotentia.htm [last accessed 4.11.14].

Aquinas, St T. (c.1264/1956) Summa Contra Gentiles, Book 3, in On the Truth of the

Catholic Faith, Summa Contra Gentiles, Book Three: Providence, Part I, trans.

V.J. Bourke (Garden City, NY: Image Books/Doubleday \& Company, Inc.).

Aquinas, St T. (c.1259) Quaestiones Disputatae de Veritate, at

http://www.dhspriory.org/thomas/QDdeVer.htm [last accessed 18.11.14].

Davies, B. (2012) The Oxford Hand N/Aford: Oxford University

Press).

AUTHOR'S DRAFT

Fakhry, M. (1958) Islamic Occasionalis (N) thitique by Averroes and Aquinas

(New York: RoutleddN.OT EOR CITATION

Freddoso, A.J. (1991) 'God's General Concurrence with Secondary Causes: Why

Conservation is not Enough', in J.E. Tomberlin (ed.) Philosophical

Perspectives, vol. 5 (Atascadero, CA: Ridgeview Publishing): 553-85.

Garrigou-Lagrange, R. (1939) Predestination (B. Herder Book Co.).

(1936) 'Prémotion Physique', in A. Vacant, E. Mangenot, and

É. Amann (eds) Dictionnaire de Théologie Catholique, vol. 13 (Paris: Librairie

Letouzey et Ané, 1936): col. 31-77.

Jerome, St (c.415) Dialogue against the Pelagians, at

http://www.ccel.org/ccel/schaff/npnf206.vi.ix.I_1.html [last accessed 24.10.14]. 
WARNING - AUTHOR COPY ONLY. NOT OFFICIAL PUBLICATION. NOT FOR CITATION. OFFICIAL VERSION IS PUBLISHED IN: INTERNATIONAL JOURNAL FOR PHILOSOPHY OF RELIGION, DOI 10.1007/s11153-015-9536-z

Malebranche, N. (1678/1997) The Search after Truth and Elucidations of the Search

after Truth, trans. and ed. T.M. Lennon and P.J. Olscamp (Cambridge:

Cambridge University Press).

Mancha, L. (2012) 'Aquinas, Suarez, and Malebranche on Instrumental Causation and Premotion', International Philosophical Quarterly 52: 335-53.

McHugh, J.A. and Callan, C.J. (1982) The Catechism of the Council of Trent

(Rockford, IL: Tan Books and Publishers, Inc; reprint of 1923 edition).

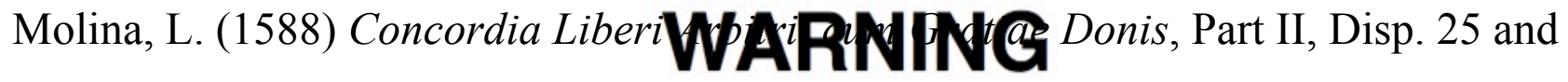

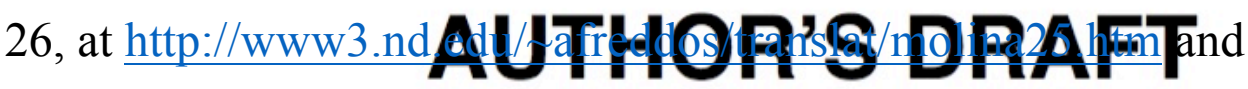

http://www3.nd.edu/ afreddos/tran@1ad/Mdlingl6.htm [last accessed 26.11.14].

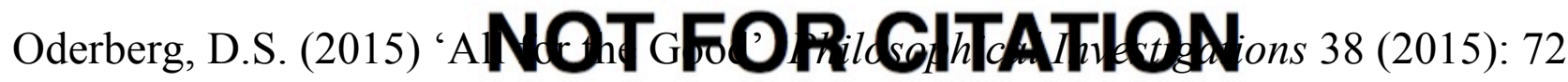
95

Ott, L. (1974) Fundamentals of Catholic Dogma (Rockford, IL: Tan Books and Publishers, Inc; reprint of 4th ed., 1960).

Phillips, R.P. (1962) Modern Thomistic Philosophy, vol. II (Westminster, MD: The Newman Press).

Pruss, A.R. (2013) 'Incompatibilism Proved', Canadian Journal of Philosophy 43: $430-7$.

Rotelle, J.E. (ed.) (2002) Saint Augustine on Genesis (Hyde Park, New York: New City Press). 
WARNING - AUTHOR COPY ONLY. NOT OFFICIAL PUBLICATION. NOT FOR CITATION. OFFICIAL VERSION IS PUBLISHED IN: INTERNATIONAL JOURNAL FOR PHILOSOPHY OF RELIGION, DOI 10.1007/s11153-015-9536-Z

Suarez, F. (1597/2002) Disputationes Metaphysicae 20-22, in A.J. Freddoso (trans.)

On Creation, Conservation, and Concurrence (South Bend, IN: St. Augustine's Press).

Weisheipl, J.A. (1983) Friar Thomas D'Aquino: His Life, Thought and Works

(Washington, DC: Catholic University of America Press).

Wilhelm, J. and Scannell, T.B. (1909) A Manual of Catholic Theology, vol. 1 (New

York: Benziger Bros.).

\section{WARNING \\ AUTHOR'S DRAFT \\ ONLY! \\ NOT FOR CITATION}

